\title{
Power Management Strategy between PV-Wind Hybrid System Using Cuckoo MPPT Techniques
}

\author{
P Suresh Babu ${ }^{1}$ | Dr. S N V Ganesh ${ }^{2}$ \\ ${ }^{1}$ PG Student, Dept of EEE, Andhra University College of Engineering, Vizag \\ ${ }^{2}$ Assistant Professor, Dept of EEE, Andhra University College of Engineering, Vizag
}

\section{To Cite this Article}

P Suresh Babu and Dr. S N V Ganesh, "Power Management Strategy between PV-Wind Hybrid System Using Cuckoo MPPT Techniques", International Journal for Modern Trends in Science and Technology, 6(11): 12-17, 2020.

Article Info

Received on 06-October-2020, Revised on 18-October-2020, Accepted on 25-October-2020, Published on 30-0ctober-2020.

\section{ABSTRACT}

The main theme of this paper is to maintain a power management strategy in grid interfaced hybrid system. Here, the PV and Wind Energy Systems considered hybrid connection systems. Wind and PV systems are more efficient DG systems, as freely available in nature. The DFIG based wind system is designed to generate $16 \mathrm{~kW}$ and Solar system is designed for rating of $20 \mathrm{~kW}$ power generation. In addition with battery management system also used for back-up purpose. An MPPT based DC-DC converters are proposed for both $P V$ and Wind systems to improve the reliability and effective power management between the systems under different load conditions. This proposed system is verified in MATLAB simulink environment.

Key Words: Wind Energy System, PV Panel, MPPT Technique, Power-management, DC-DC Converter.

\section{INTRODUCTION}

In the last decade, the plants related to fossil fuels such as coal, gas and petroleum plays a key role to meet the load demand. But the major concern with these plants is that, these plants may cause global warming, pollution and releases carbon di-oxide which is harmful to humans and plants. Renewable energy systems has the solution in power plants to overcome these problems. The most reliable DG systems are PV and wind as freely available in nature, high efficient and economical.

The renewable energies present in this paper as solar, wind and fuel cell system. Solar system converts irradiance and temperature into electrical energy. And also to maintain constant dc from the solar system an MPPT based dc-dc converter is implemented. As per literature, there are approximately 26 MPPT techniques available. Out of these the basic perturb \& observe technique is considered.

Generation of electrical energy from wind energy is obtained with the help of wind turbine system. The wind turbine consists of blades, hub, gear mechanism used to change low speed shaft to high speed shaft and generator. From the literature point the available generators are synchronous generator, induction generator.

There are two types in induction generator i.e SCIG and DFIG. In dfig the rotor is recycled and regulated by using two back-back converters and fed to stator. The output from the wind system is converted to dc voltage with the help of rectifier.

And also this paper mainly concentrate on fuel energy based renewable system. In this, the fuel energy is converted to electrical energy by electrolyte process. The proton exchange membrane type fuel system is considered in this 
paper. In this case the hydrogen fuel is reacted with oxidant to generate electrons. The output of fuel cell is applied to a conventional Dc-Dc converter to improve the voltage levels to meet the requirements. A combined voltage from the Dc bus is applied to inverter to synchronize with grid system. And with these combination, this paper proposes the concept to meet the load demand under various conditions.

\section{PROPOSED HYBRID ENERGY SYSTEM:}

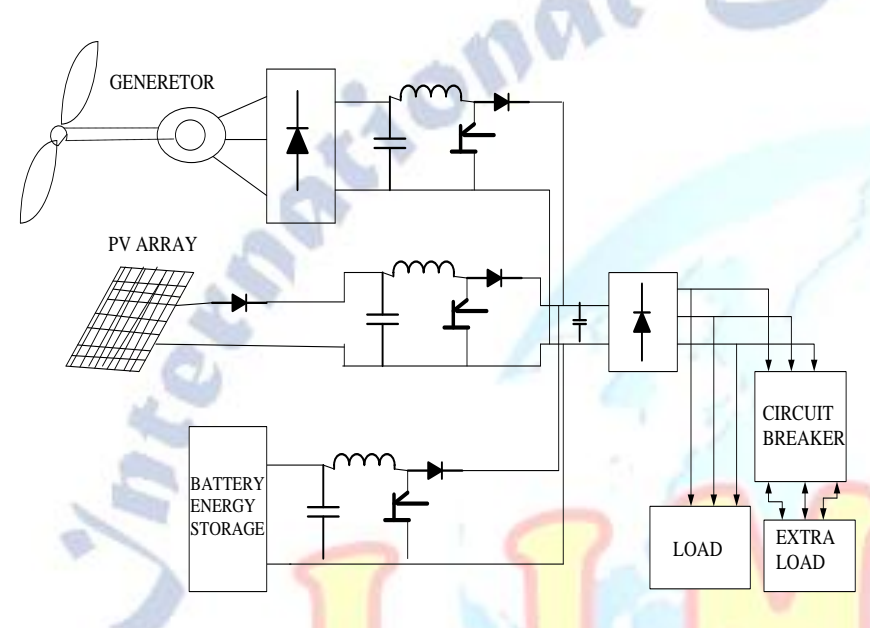

Figure 1: Configuration of Hybrid Energy System

The above figure 1 , shows the structure of hybrid system with grid interfaced system. This hybrid system is a combination of wind, solar and fuel cell system. Here, this three systems are connected at DC bus. The energy from PV and FC is $\mathrm{DC}$ side, the energy of wind system is converter to DC with the help of rectifier. This Common DC bus is applied to Inverter to achieve AC side and connected to grid. The synchronization between hybrid system and grid is maintained with PWM controller.

\section{PV System:}

In this, the solar radiation is converted to electrical energy with the help of photon effect. The initial energy from the solar panel is electric current and converted to dc voltage with the help of electrical equivalent circuit. The main problem with solar system, the output is not constant because of variations in solar irradiance. In order to maintain solar output as constant, this paper is implemented with MPPT based DC-DC converter.

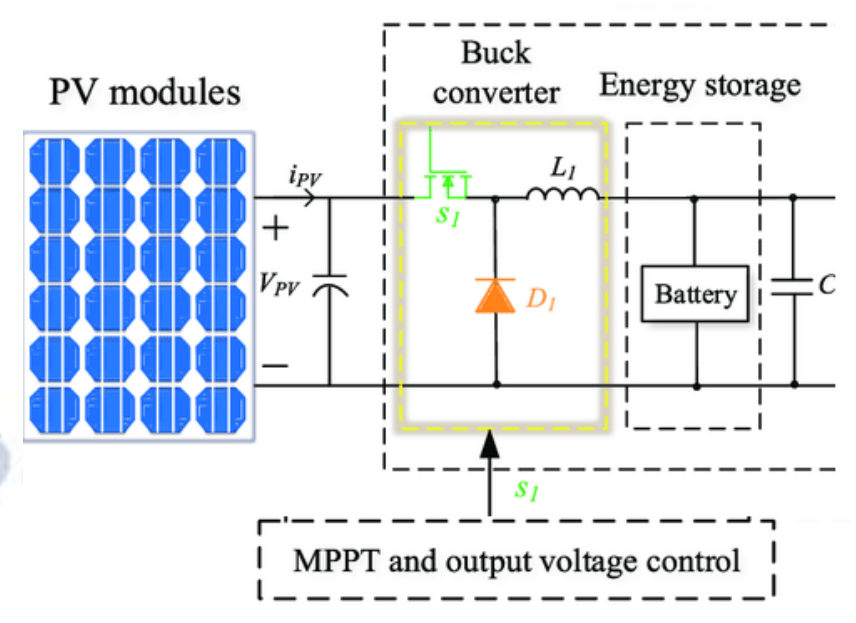

Figure 2: Architecture of PV System

The mathematical analysis of PV system is expressed as,

$I=I_{p h}-I_{D}-I_{s h}$ $I=I_{p h}-I_{o}\left[e^{\left(\frac{q V_{D}}{n K T}\right)}\right]-\left(\frac{V_{D}}{R_{s}}\right)$

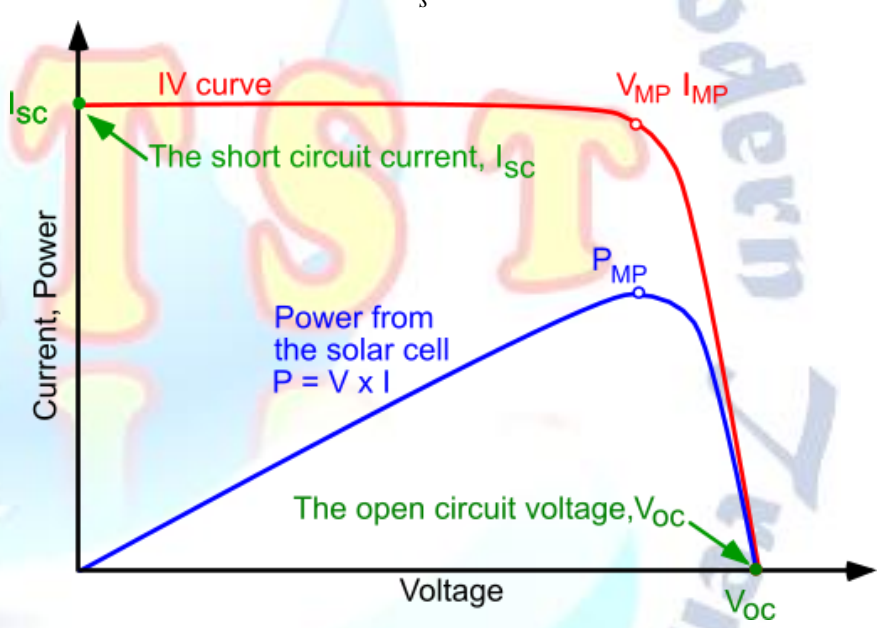

Figure 3: P-V \& I-V Characteristics of Solar system MPPT Technique:

The purpose of MPPT technique is to design a suitable reference signal required for PWM of DC DC converter this MPPT technique increases the efficiency of DG system and battery charging controllers. This paper proposes MPPT controller and compare the performances of each MPPT the chosen MPPT techniques are (a) Petrob and observe.

\section{WIND Energy System:}

In wind system the energy conversion can be done in two stages, in first stage the wind speed is converted to mechanical power with the help of wind turbine and later with help of generator it converted to electrical energy. Generally, there are two types of generators available in market i.e synchronous generator and induction generator. DFIG generator is proposed in this paper. 
The mathematical analysis for wind energy system is expressed as below. The mechanical output power from the wind turbine as

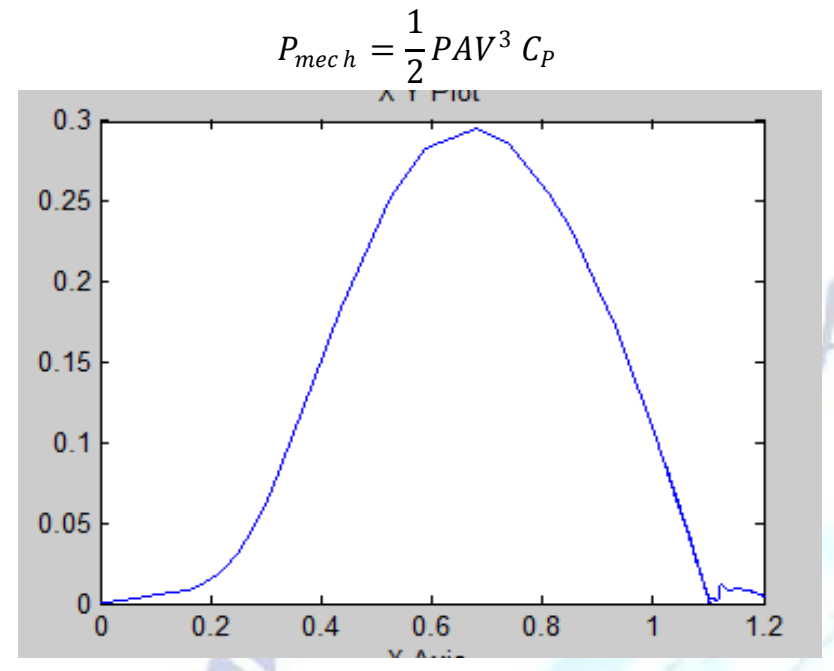

Figure 4: Tip Speed Ratio Vs Coefficient of Power MODELLING AND DESIGN OF DFIG:

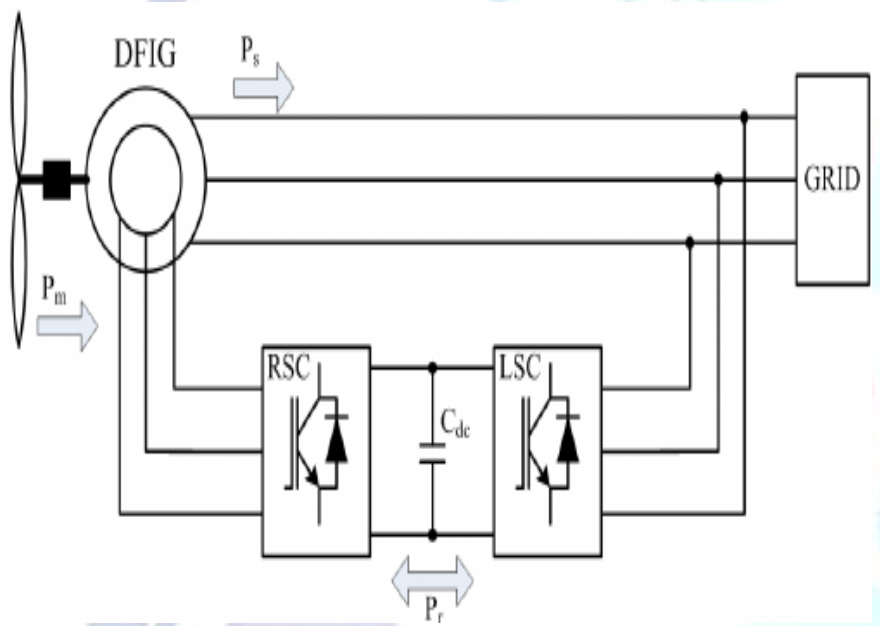

Figure 5: Back-back Converters with DFIG

The structure of doubly fed induction generator with two back-back converters are shown in figure 5 . Here, the purpose of two converters is to control and regulate the rotor power. These converters acts as rectifier and inverter combination called as rotor side and grid side converters. The control diagrams for these two converters are implemented with reference signals of stator and rotor parameters. The mathematical analysis for dfig system is obtained with induction generator equivalent circuit as shown in figure 6.

This mathematical analysis for RSC and GSC as shown in figure 6 is obtained by writing KVL and KCL equations.

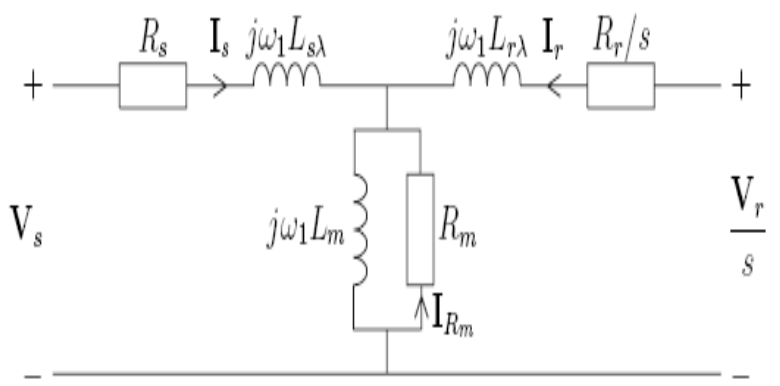

Figure 6: DFIG Equivalent Circuit

From KVL in figure-6,

$V_{s t}=j w_{1} L_{m}\left(I_{r}+I_{s}+I_{m r}\right)+j w_{1} L_{s t} I_{t s}+R_{s t} I_{s t}$

$V_{r} / s=j w_{1} L_{m}\left(I_{r}+I_{s}+I_{m r}\right)+j w_{1} L_{1 r} I_{t s}+R_{r} / s * I_{r}$

$0=j w_{1} L_{m}\left(I_{r}+I_{s}+I_{m r}\right)+R_{m} I_{m r}$

The expression for electromagnetic torque is shown as

$T_{e}=3 n I_{m} \psi_{r} I_{r}^{*}$

The stator and rotor powers are shown as

$P_{s}=3 R_{s} I_{s}^{2}+3 R_{m r} I_{m r}^{2}+3 w_{1} I_{m}\left[\psi_{m} I_{r}^{*}\right]$

$P_{r}=3 R_{m r} I_{m r}^{3}-3 w_{1} I_{m}\left[\psi_{m} I_{r}^{*}\right]$

\section{Control Diagram for RSC \& GSC Converters:}

The reference signals required for two converters of DFIG is implemented with active and reactive powers in dq-axis of DFIG.

$\bar{V}_{r}=\bar{I}_{r} R_{r}+\frac{d \psi_{r}}{d t}$

$\bar{\psi}_{r}=\bar{I}_{r} L_{r}+{ }_{s} e^{-j \epsilon} M \bar{I}_{r}$

Substituting the value of $\bar{\psi}_{r}$ in above equation e get $\bar{V}_{r=} \bar{I}_{r} R_{r}+\frac{d}{d t}\left(L_{r} \bar{I}_{r}-\frac{M^{2}}{L_{s}} \bar{I}_{r}+\frac{M}{L_{s}} \bar{\psi}_{s} e^{-j \epsilon}\right)$

Figure 7, shows the control diagram for rotor and grid side converters of DFIG system. Here, the system active powers are compared with reference powers to generate dq-reference currents in inner loop. And in the outer loop these dq-reference currents are compared with grid currents and applied to PWM generators for RSC and GSC. 


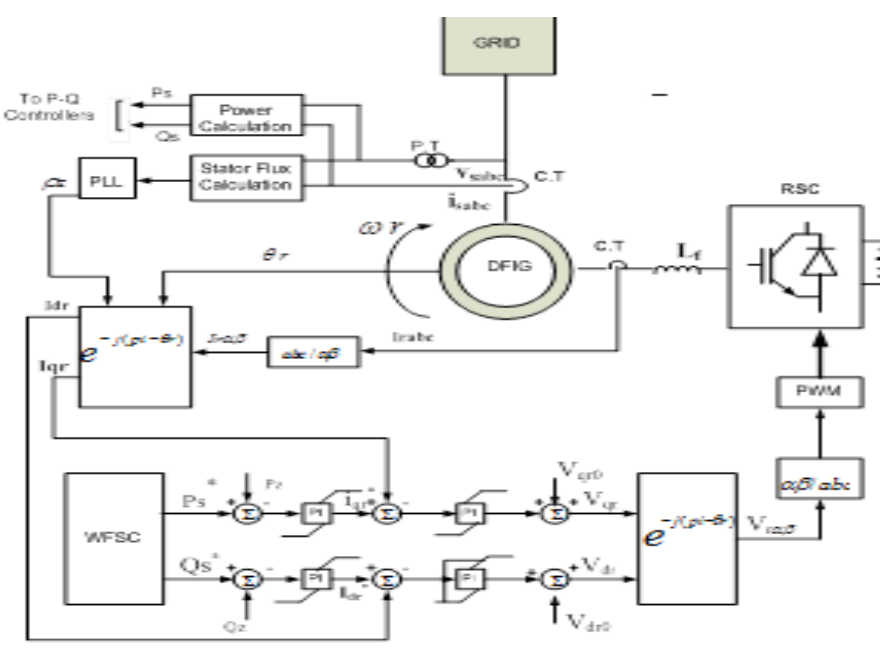

Figure 7: DFIG Converters Control Diagram

\section{SIMULATION RESULTS:}

The complete grid connected hybrid system is given in figure 9. The PV system consists of two PV arrays with two PV module in series mode and boost converter. The ratings of PV, Wind energy and battery energy system are $16 \mathrm{KW}$ and $20 \mathrm{KW}$ respectively for $11 \mathrm{kV}, 50 \mathrm{MW}$ power grid connection with load connected to the system.

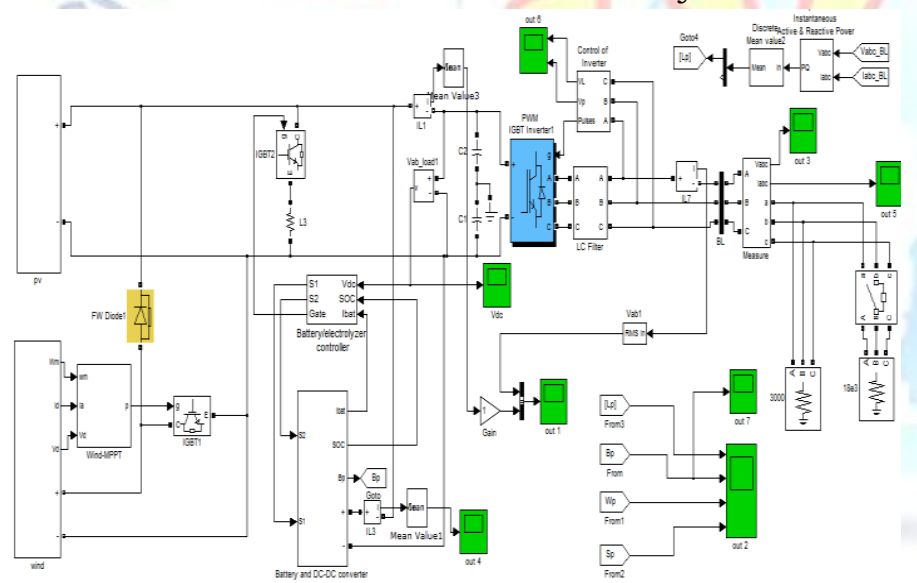

Figure 5: The Simulation Diagram for The Hybrid Wind-PV System

\section{SIMULATED GRAPHS:}

Fig. 6 shows the simulation result for the proposed system to show the power management strategies. Here, the load sharing is chosen between PV, battery and wind system according to their generations. The solar system generates $10 \mathrm{~kW}$ during $0 \mathrm{~s}$ to $2 \mathrm{~s}$ and $8 \mathrm{kw}$ between $2 \mathrm{~s}$ to $6 \mathrm{~s}$. And the wind system generates $9.8 \mathrm{~kW}$ between $0 \mathrm{~s}$ to $4 \mathrm{~s}$ and $6 \mathrm{~kW}$ during $4 \mathrm{~s}$ to $6 \mathrm{~s}$. The demand for load to this system is approximately $47 \mathrm{~kW}$ and it is changed to $38 \mathrm{~kW}$ during the period $3 \mathrm{~s}$ to $6 \mathrm{~s}$.
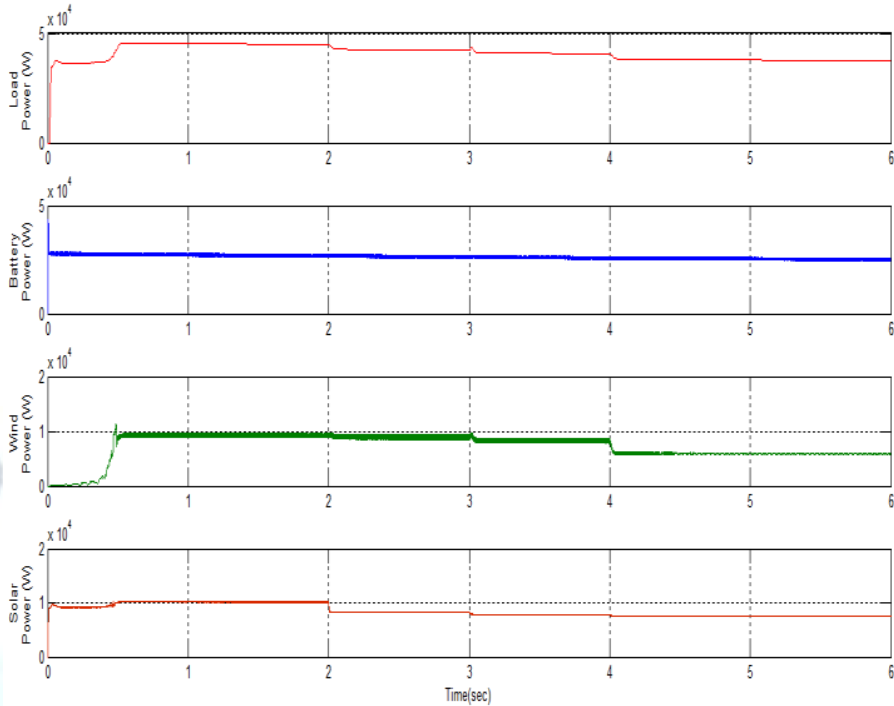

Fig. 6 Simulation Result for (a) Load Demand, (b) Solar Power, (c) Wind Power and

(d) Battery Power
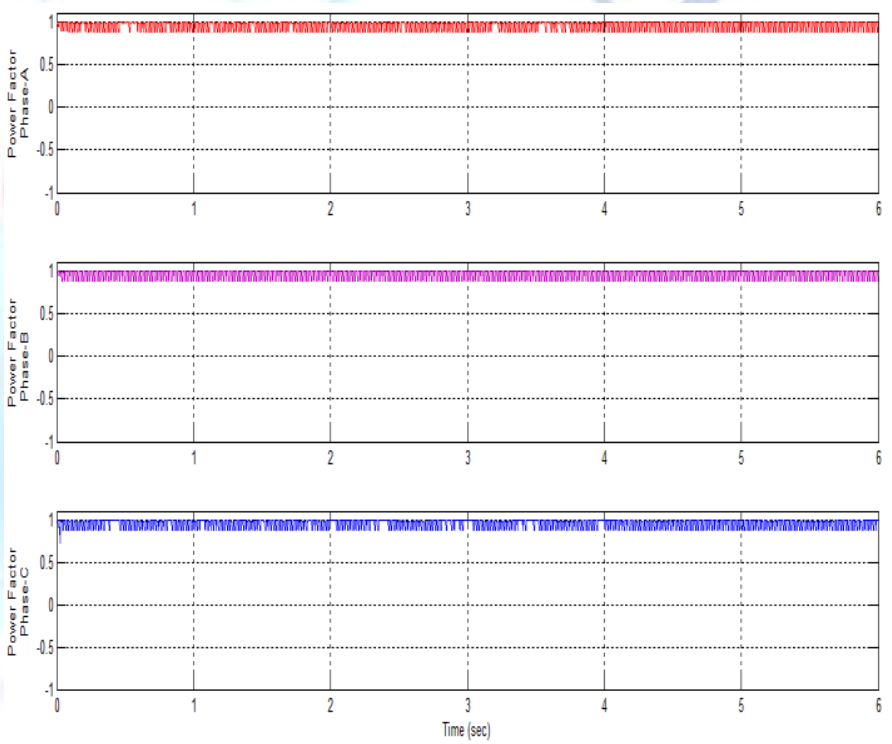

Fig. 7. Power Factors for Inverter Load Current

Fig. 7 shows the simulation results for power factors of phase- $a$, phase- $b$ and phase-c of load voltage and current. Here in this case, the load is taken as linear balanced load, so that the power factor is almost reaches to unity. Fig. 8 shows the simulation results for load voltage and current. 

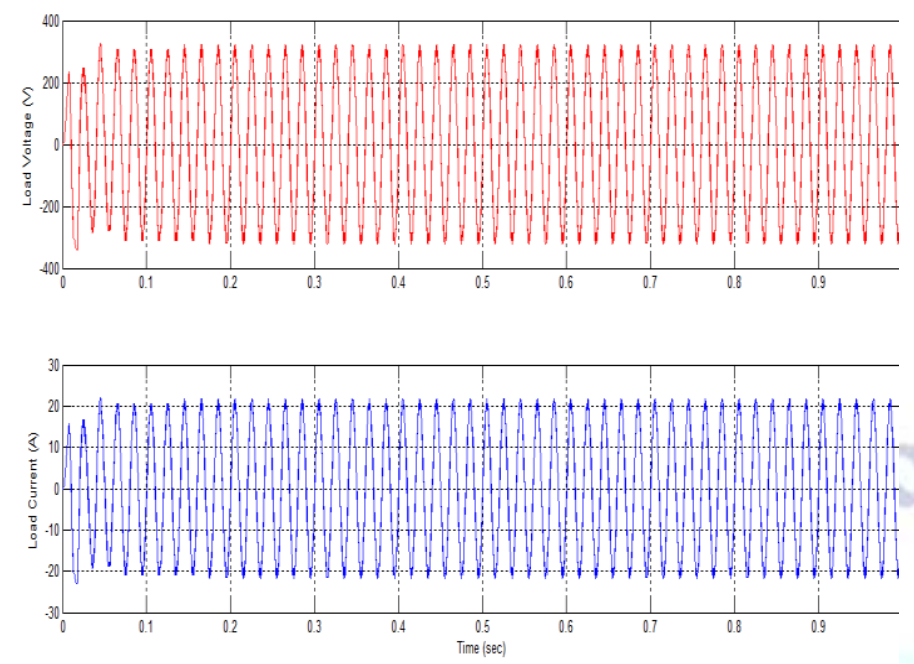

Fig. 8 Simulation result for Load Voltage and Current

Fig. 9 shows the simulation result for the proposed system to show the power management strategies implemented with PO MPPT controller. Here, the load sharing is chosen between PV, battery and grid system according to their generations. The irradiance to solar system is considered in variable mode i.e during $0 \mathrm{~s}$ to $4 \mathrm{~s}$ the irradiance is $1000 \mathrm{w} / \mathrm{m} 2,800 \mathrm{w} / \mathrm{m} 2$ applied during $4 \mathrm{~s}$ to $5 \mathrm{~s}$ and later it changed to $900 \mathrm{w} / \mathrm{m} 2$. Based on these conditions, the output from the solar system like $10 \mathrm{~kW}$ during $0 \mathrm{~s}$ to $4 \mathrm{~s}$ and $8.2 \mathrm{kw}$ between $4 \mathrm{~s}$ to $5 \mathrm{~s}$ and again it raised to $9 \mathrm{~kW}$ after $5 \mathrm{~s}$. The wind energy system generates $4.8 \mathrm{~kW}$ between $0 \mathrm{~s}$ to $4 \mathrm{~s}$ with wind speed of $9 \mathrm{~m} / \mathrm{s}$, it generates $3.6 \mathrm{~kW}$ during $4 \mathrm{~s}$ to $5 \mathrm{~s}$ with wind speed of $7 \mathrm{~m} / \mathrm{s}$ again after $5 \mathrm{~s}$ the wind speed is changed to $9 \mathrm{~m} / \mathrm{s}$ and generates $4.8 \mathrm{~kW}$. The demand for load to this system is approximately $14 \mathrm{~kW}$ and it is changed to $45 \mathrm{~kW}$ during the period $4 \mathrm{~s}$ to $5 \mathrm{~s}$.
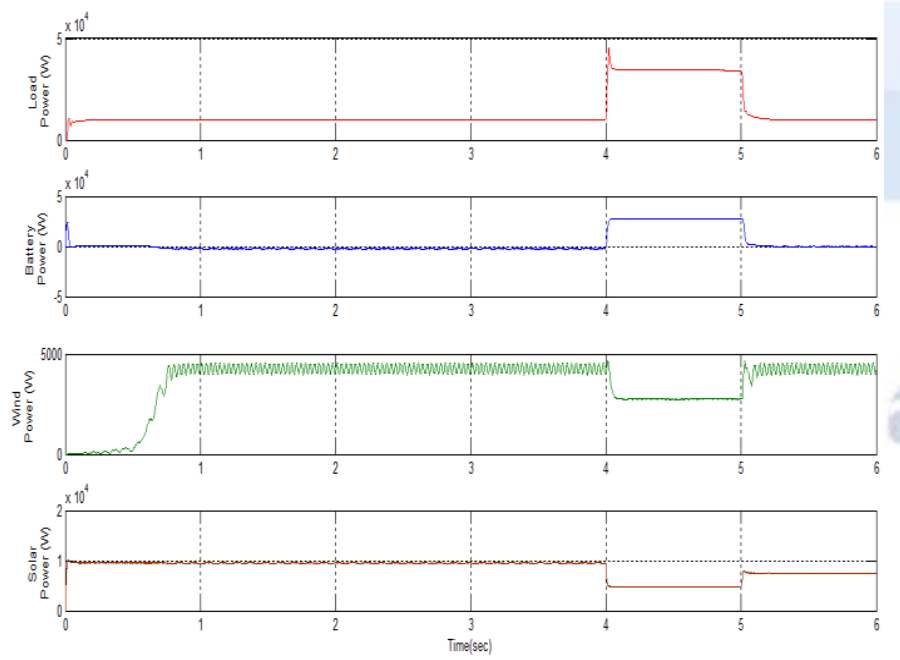

Fig. 9. Simulation Result for (a) Load

Demand, (b) Battery Power, (c) Solar Power and (d) Wind Power with PO Controller

\section{CONCLUSION}

The hybrid solar, wind and fuel cell based grid connected system is implemented in this paper. A MPPT technique is used to improve the reliability of PV system, and the generator for wind system is implemented with back-back converters with DFIG system, proton exchange membrane type fuel cell system based hybrid system is designed in this paper. This system is tested for different load demand conditions. To improve the reliability and efficiency, the proposed hybrid system is implemented with MPPT techniques such as PO techniques. The results for hybrid system with different MPPT techniques is analyzed under different load levels. This proposed system is tested in Matlab and verified the results.

\section{REFERENCES}

[1] Joanne Huil, Alireza Bakhshai, and Praveen K. Jain, "A Hybrid Wind-Solar Energy System: A New Rectifier Stage Topology ", in Applied Power Electronics Conference and Exposition (APEC), 2010 Twenty-Fifth Annual IEEE, pp 156-161, 21-25 Feb. 2010

[2] S. K. Kim, J.H Jeon, C. H. Cho, J. B. Ahn, and S. H. Kwon, "Dynamic Modeling and Control of a Grid-Connected Hybrid Generation System with Versatile Power Transfer," IEEE Transactions on Industrial Electronics, vol. 55, pp. 1677-1688, April 2008.

[3] Design and Development of Energy Management System for DG Source Allocation in a Micro Grid with Energy Storage System. S. Ezhilarasan, P. Palanivel and S. Sambath. Indian Journal of Science and Technology, Vol 8(13), 58252, June 2015

[4] Wind and Solar Power Systems Design Analysis and Operation Second Edition, by Mukund R. Patel, Taylor \& Francis Group Publishing Co.

[5] Y.M. Chen, Y. C. Liu, S. C. Hung, and C. S. Cheng, "Multi-Input Inverter for Grid-Connected Hybrid PV/Wind Power System," IEEE Transactions on Power Electronics, vol. 22, May 2007.

[6] S. Jain, and V. Agarwal, "An Integrated Hybrid Power Supply for Distributed Generation Applications Fed by Nonconventional Energy Sources," IEEE Transactions on Energy Conversion, vol. 23, June 2008.

[7] D. Das, R. Esmaili, L. Xu, D. Nichols, "An Optimal Design of a Grid Connected Hybrid Wind/Photovoltaic/Fuel Cell System for Distributed Energy Production," in Proc. IEEE Industrial Electronics Conference, pp. 2499-2504, Nov. 2005.

[8] An Improved Artificial Fish Swarm Optimization for Proficient Solving of Advanced Unit Commitment Problem with Wind Energy and Pumped Hydro Storage. R. Soundarapandian and R. Jayashree. Indian Journal of Science and Technology, Vol 7(S6), 95-104, October 2014

[9] Simultaneous Coordinated Design of Power System Stabilizer 3 Band (PSS3B) and SVC by using Hybrid Big Bang Big Crunch Algorithm in Multi-Machine Power System. S. Jalili and R. Effatnejad. Indian Journal of Science and Technology, Vol 8(S3), 62-71, February 2015

[10] Comparative Analysis of Nature Inspired Algorithms Applied to Reactive Power Planning Studies. R. Ambika, R. 
Rajeswari and A. Nivedita. Indian Journal of Science and Technology, Vol 8(5), 445-453, March 2015

[11] Niraj Garimella and Nirmal-Kumar C. Nair, "Assessment of Battery Energy Storage Systems for Small-Scale Renewable Energy Integration," IEEE Conference, January 2009.

[12] Dezso Sera, Tamas Kerekes, Remus Teodorescu and Frede Blaabjerg, "Improved MPPT Algorithms for Rapidly Changing Environmental Conditions," IEEE Conference, September 2006.

[13] Evaluation of Uncertainty in Hybrid Plants, Including Wind Turbine, Photovoltaic, Fuel Cell, and Battery System using Fuzzy Logic. Milad Gheydi Reza Effatnejad and Parviz Ramezanpour. Indian Journal of Science and Technology, Vol 7(2), 113-122, February 2014.

[14] Dynamic Analysis of PMSG Wind Turbine under Variable Wind Speeds and Load Conditions in the Grid Connected Mode. Maziar Izadbakhsh, Alireza Rezvani Majid Gandomkar and Sohrab Mirsaeidi. Indian Journal of Science and Technology, Vol 8(14), 51864, July 2015. 